\title{
Article \\ A Novel Approach to Enhance Crude Oil Recovery Ratio Using Selected Bacterial Species
}

\author{
Hakima A. Althalb ${ }^{1, *}$, Izzeddin M. Elmusrati ${ }^{1}$ and Ibrahim M. Banat ${ }^{2} \mathbb{D}$ \\ 1 Environment Research Department, Libyan Petroleum Institute, Tripoli 6431, Libya; i.elmusrati@lpilibya.com \\ 2 School of Biomedical Sciences, University of Ulster, Coleraine BT52 1SA, UK; im.banat@ulster.ac.uk \\ * Correspondence: h.althalb@lpilibya.com
}

check for updates

Citation: Althalb, H.A.; Elmusrati, I.M.; Banat, I.M. A Novel Approach to Enhance Crude Oil Recovery Ratio Using Selected Bacterial Species. Appl. Sci. 2021, 11, 10492. https://doi.org/ 10.3390/app112110492

Academic Editors: Kun Sang Lee and Riyaz Kharrat

Received: 3 October 2021 Accepted: 2 November 2021 Published: 8 November 2021 Corrected: 18 March 2022

Publisher's Note: MDPI stays neutral with regard to jurisdictional claims in published maps and institutional affiliations.

Copyright: (c) 2021 by the authors. Licensee MDPI, Basel, Switzerland. This article is an open access article distributed under the terms and conditions of the Creative Commons Attribution (CC BY) license (https:// creativecommons.org/licenses/by/ $4.0 /)$.
Abstract: The high viscosity and low flow properties of some crude oil make them difficult to extract from oil reservoirs. This study investigated the mechanisms responsible for the enhancement of oil recovery using fractured dolomite core models. Bacterial strains, Nocardia cyriacigeorgica, Bacillus species, and Pseudomonas putida, isolated from Libyan oil fields, had the ability to biotransform heavy crude oil by reducing its viscosity and converting heavier components into lighter ones. The efficiencies of the three bacterial strains were assessed using sand-packed column experiments through the injection of bacteria to mimic in-situ oil recovery. The optimum biotransformation values of Libyan Bouri crude oil were determined as 77.1, 61.2, and 61.1\% using the Bacillus sp., P. putida, and Nocardia cyriacigeorgica, respectively, at $55^{\circ} \mathrm{C}$. Viscosity analyses showed that these strains resulted in the reduction of the viscosity of the crude oil at two different temperatures of 37 and $55^{\circ} \mathrm{C}$. The highest recovery of residual oil was about $11.3 \%$ using Bacillus sp. The study confirmed that the selected bacterial species were capable of displacing additional oil under simulated oil field conditions.

Keywords: viscosity; Nocardia cyriacigeorgica; Bacillus species; Pseudomonas putida; dolomite core; biotransformation

\section{Introduction}

Oil production faces a decline in many oil fields in different parts of the world because of the withdrawal of large amounts of high-flowing oil. There is a necessity, therefore, to apply various methods to enhance oil recovery from existing oilfields worldwide. The extraction of heavy crude oil needs higher energy input due to its resistance to flow, high density, and low American Petroleum Institute (API) gravity of less than 20 [1].

Viscosity is a measure of a fluid's resistance to flow. It is one of the most important properties of a fluid and plays a very important role in the petroleum industry. The viscosity of a crude oil therefore affects the ability to pump it out of the ground. Small changes in viscosity can have a dramatic impact on the properties of petroleum fluids. Oil mobility can be improved by a reduction of oil viscosity; therefore, lowering the viscosity of crude oil is essential in the oil extraction industry. Thus, the discovery of new technologies that reduce the viscosity of crude oil with minimum requirements to raise its temperature is highly valued.

Microbial enhanced oil recovery (MEOR) has been proposed for many years as a cheap and effective alternative technique. MEOR is a good alternative in improving the recovery of crude oil from reservoir rocks by using microorganisms and their metabolic byproducts [2]. Microbial enhanced oil recovery (MEOR) is used in the third phase of oil recovery from a well, which is the tertiary oil recovery stage [3]. Many investigations of the MEOR technique have injected microorganisms or their products into oil reservoirs to improve the efficiency of oil recovery [4-6]. Up to $50 \%$ of the residual oil can be extracted by this exceptionally low operating cost technology [7]. Bacteria can ferment readily available organic compounds to produce gases such as $\mathrm{CH}_{4}, \mathrm{CO}_{2}$, and $\mathrm{H}_{2}$. These gases, which are produced in situ, can increase the pressure of the reservoir and enhance oil recovery. 
In addition, they mobilize the crude oil through reducing its viscosity which enhances its recovery [8].

This study aimed to demonstrate the potential of using bacterial isolates Bacillus species, Pseudomonas putida, and Nocardia cyriacigeorgica in the biotransformation of heavy crude oil $\left(26^{\circ}\right.$ API) and to evaluate the viscosity reductions of the heavy crude oil to enhance its flow properties and increase its extraction efficiency from the reservoir.

\section{Materials and Methods}

\subsection{Characterization of Soil and Oil Samples}

Subsurface soil samples contaminated with heavy crude oil were collected from an oil-contaminated site in Libya, transferred to a microbiological laboratory of the Libyan Petroleum Institute, and stored at $4{ }^{\circ} \mathrm{C}$ until use. The soil was air-dried for $48 \mathrm{~h}$ and all samples mixed to obtain one homogenous sample. Then, soil was sieved to $2 \mathrm{~mm}$ to remove gravel and stones. Soil $\mathrm{pH}$ was determined using soil suspensions in water as described by $[9,10]$. Soil texture was analyzed using a Master Sizer 2000 (Malner International, London, UK). Mineralogy analysis was carried out using X-ray diffraction (XRD) (New York, NY, USA). Soil moisture content and water holding capacity were measured as described by [11]. Maximum water holding capacity (WHC) was determined as described by [12]. The petroleum products present in the soil samples were extracted using a Soxhlet Extraction System, New York, NY, USA (test method $35-40^{\circ} \mathrm{C}$ ) with dichloromethane to measure the total petroleum hydrocarbons (TPH) level. The heavy oil sample used in this study was obtained from Bouri oil field, Libya. The Bouri crude oil viscosity was measured using rotational viscometer, API gravity, and a CVM 3000 Viscometer (Shenzhen, China).

\subsection{Isolation of Hydrocarbon Degrading Bacteria Using Heavy Crude Oil as Carbon Source}

One gram of the homogenized soil sample was mixed with $10 \mathrm{~mL}$ of distilled water and vortexed thoroughly; $5 \mathrm{~mL}$ of the supernatant served as an inoculum for the first enrichment containing $50 \mathrm{~mL}$ of enrichment medium (g/L) $\left(\mathrm{NH}_{4}\right)_{2} \mathrm{SO}_{4}(1.5) ; \mathrm{NaH}_{2} \mathrm{PO}_{4}$. $\mathrm{H}_{2} \mathrm{O}$ (1.5); $\mathrm{K}_{2} \mathrm{HPO}_{4}$ (4.65); $\mathrm{KCl}(0.1) ; \mathrm{MgSO}_{4} \cdot 7 \mathrm{H}_{2} \mathrm{O}(0.2)$; yeast extract (0.5); peptone (0.5); casamino acid (0.5); and trace elements $(2.0)(\mathrm{pH}=7.1)$, and varying Bouri crude oil concentrations of $1.0,2.0$, and $3.0 \%(v / v)$ were added. Cultures were incubated with shaking for $14 \mathrm{~d}$ at 37 and $55{ }^{\circ} \mathrm{C}$ for the purpose of isolating hydrocarbon-utilizing bacteria from oil contaminated soil. Three different isolates (Nocardia cyriacigeorgica, Bacillus species, and Pseudomonas putida) showing the best growth on heavy crude oil were selected and transferred to a mineral medium containing (g/L) $\mathrm{NaNO}_{3}(4) ; \mathrm{Na}_{2} \mathrm{HPO}_{4}(0.5) ; \mathrm{KH}_{2} \mathrm{PO}_{4}$ (1.5); $\mathrm{KCl}(0.1) ; \mathrm{MgSO}_{4} \cdot 7 \mathrm{H}_{2} \mathrm{O}(0.2) ; \mathrm{CaCl}_{2}$ (0.01); $\mathrm{FeSO}_{4} \cdot 7 \mathrm{H}_{2} \mathrm{O}$ (0.0011); and yeast extract (0.1). The medium was supplemented with $1 \mathrm{~mL}$ of the trace elements solution [13] and optimum concentration $2.0 \%(v / v)$ of crude oil. Then, $50 \mathrm{~mL}$ cultures were grown in $250 \mathrm{~mL}$ Erlenmeyer flasks and incubated with orbital shaking at $150 \mathrm{rpm}$ for $21 \mathrm{~d}$ at 37 and $55^{\circ} \mathrm{C}$.

The three bacterial isolates with the ability to grow on target hydrocarbons were assessed further for growth rate, crude oil biotransformation, viscosity reduction, and oil recovery. Growth of the isolated bacterial strains on different concentrations of crude oil was evaluated by measuring culture absorbance at $600 \mathrm{~nm}$ using a spectrophotometer (Eppendorf Biophotometer plus, Hamburg, Germany).

\subsection{Identification of Isolates by $16 S \mathrm{rDNA}$ Analysis}

DNA was extracted from the bacterial colonies according to the protocol described by Sigma's GenElute Bacterial Genomic Kit. Genomic DNA from hydrocarbon degraders were amplified by polymerase chain reaction (PCR) using the specific bacterial primers $27 \mathrm{f}$ and $1525 \mathrm{r}$. These are universal primers that bind at the conserved 5 and $3^{\prime}$ ends of $16 \mathrm{~S}$ rDNA of the eubacteria. PCR amplification was performed as described by [14]. All reagents used were from Bioline, (London, UK). PCR was performed with a Biometra Thermal Cycler (Jena, Germany). In order to check the sizes of the PCR products, $4 \mu \mathrm{L}$ of the PCR reactions were analyzed by $1.0 \%$ agarose gel electrophoresis in TAE (Tris acetic 
acid EDTA buffer, $1 \% w / v ; 30 \mathrm{~min}$ at $100 \mathrm{~V}, 0.5 \times \mathrm{TBE})$, stained with ethidium bromide, and visualized under UV light using image analysis software (Bio-Rad Gel Doc, Flour-S multi-imager, Hertfordshire, UK), according to [15]. The size of the amplified fragments was estimated by comparing with a $100 \mathrm{bp}$ molecular size marker.

The PCR products were cleaned up using an ExoSAP-IT PCR clean-up kit, the protocol for which consists of a single pipetting step (enzyme mixture addition), a $15 \mathrm{~min}$ incubation at $37^{\circ} \mathrm{C}$ followed by a further $15 \mathrm{~min}$ incubation at $80^{\circ} \mathrm{C}$ for enzyme inactivation, and then the PCR for products were sequenced by Geneius Laboratories Ltd. (based on Newcastle University campus, UK) using Sanger sequencing based on a big dye terminator using an ABI 3730xl DNA sequence. Sequences were viewed using MEGA software version 4.0. A contiguous sequence using forward and reverse sequences was made, and the contiguous sequences were submitted into BLAST for comparison with known databases.

\subsection{Sand-Packed Column Experiment}

Five core samples and four sand packs were collected from the Sirte Basin and formation type (Dolomite), Concession 11 (Alghni Field, northeast of Libya), sand-packed model $(4 \mathrm{~cm}$ in diameter; and $30 \mathrm{~cm}$ in length) were prepared with different grain size. The oil sample was heated to $65^{\circ} \mathrm{C}$ for $960 \mathrm{~h}$. $\mathrm{K}=200$ psi net confining stress, $\mathrm{Q}=100$ psi Helium. The dolomite sandstone core plugs were drilled in horizontal and vertical directions using a diamond core bit with water as the bit coolant and lubricant. The plug sample dolomite sandstone cores (absolute permeability $230 \times 10^{-2} \mu \mathrm{m}^{2}$ ) were extracted of hydrocarbons using toluene, leached of salt using methanol, and oven dried at $80^{\circ} \mathrm{C}$. A silver nitrate solution was used to ensure the removal of salts present in the pore spaces. The clean, dry samples were subjected to various analyses to determine permeability, porosity, and grain density values, and were saturated with filtered, sterilized formation water for $12 \mathrm{~h}$ in a desiccator under vacuum. The formation water was collected from one of the Libyan oil fields. The experimental procedures and equipment specifications were tested according to API RP 40 (recommended practice for core analysis).

A model of an oil-saturated dolomite formation column was used to mimic the reservoir condition. The crashed dolomite cores saturated with Bouri oil were placed in the packed column apparatus and heated in the oven at $50{ }^{\circ} \mathrm{C}$, then were saturated with 5-6 pore volume formation water until no further oil was produced. The pore volume $(\mathrm{PV})$ was calculated as the difference in the wet and dry weights of the core. The residual oil was calculated by measuring the amount of oil produced from water flooding. Then, 5-6 PV heavy crude oil was injected until no more water was produced (i.e., it reached the irreducible water saturation, (Swr)). The initial oil saturation of the cores was calculated volumetrically from the amount of injected oil and produced water. Further extra oil recovery was determined by injected 5-6 PV of the bacterial culture as a tertiary recovery.

The $24 \mathrm{~h}$-grown isolates in Luria Bertani broth (LB) served as the inoculum for the packed column experiment, $\left(\mathrm{OD} 600=0.764 ; 32.8 \times 10^{7} \mathrm{CFU} / \mathrm{mL}\right.$ for Nocardia cyriacigeorgica, OD600 $=1.88 ; 21.8 \times 10^{7} \mathrm{CFU} / \mathrm{mL}$ for Bacillus species, and OD600 = 1.734; $47.3 \times 10^{7} \mathrm{CFU} / \mathrm{mL}$ for Pseudomonas putida). The bacterial inoculum was injected into the core and the column model was incubated for 12 weeks at $55^{\circ} \mathrm{C}$. A control experiment was performed without injection of the isolates at the same conditions. Core columns were incubated under anaerobic conditions and simulated reservoir conditions (pressure, temperature $55^{\circ} \mathrm{C}$, and flow rate).

Samples were taken to measure the viscosity reduction and oil recovery. The residual crude heavy oil in the core was measured from the volume of oil produced. The extra recovered oil was collected and measured using graduated tubes, and then analyzed by GC-FID for determining the biotransformation of heavy crude oil. The $\mathrm{pH}$ of the aqueous phase in the packed column was also measured before and during the incubation period. 


\subsection{Gas Chromatography Hydrocarbon Analysis}

The collected oil fractions from the water flood before and after the incubation with bacteria strains were analyzed by GC. This was done to assess the effect of different bacterial species on the biodegradation of Bouri crude oil and to determine whether the biotransformation significantly depended on temperature as an important parameter.

The crude oil was extracted from core column after 12 weeks of incubation using liquid-liquid extraction techniques by a mixture of $n$-hexane and dichloromethane (1:1) for GC analysis. The extracted solution was then dried through solvent-washed anhydrous sodium sulfate in Whatman \#50 paper. The remaining organic phase of the extract was removed with a dichloromethane solvent and put in a sealed flask for subsequent analysis. Gas chromatography analyses were carried out on the initial sample (time $=0$ day) and at the end of the experiments (time $=84$ days) to evaluate the potential of biotransformation rate, as described by $[16,17]$. Total petroleum hydrocarbon and $n$-alkane concentrations were determined using a DHA (Carbon Distribution) Model No: CP3800.

\subsection{Bacterial Effect on Oil Viscosity Measurements}

The viscosity density and specific gravity of the crude oil were determined at $50{ }^{\circ} \mathrm{C}$ by a digital viscometer SVM 3000 (Anton Paar Company, Graz, Austria). The percentage of oil viscosity reduction, $\mu \mathrm{r}$, was calculated as:

$$
\mu \mathrm{r}=(\mu \mathrm{bm}-\mu \mathrm{am} / \mu \mathrm{bm}) \times 100
$$

where $\mu \mathrm{bm}$ and $\mu \mathrm{am}$ are the oil viscosity before microbial treatment and after microbial treatment, respectively. API gravity was determined by the following equation [18]:

$$
\mathrm{API}=\frac{141.5}{\text { ro }}-131.5
$$

\subsection{Rheological Investigations}

Bouri crude oil was separated from the packed column using a separation technique, and the rheological study was performed using Rotational Viscometer (CV100) at $50^{\circ} \mathrm{C}$ and $12 \mathrm{~s}^{-1}$ shear rate to measure the viscosity of crude oil at 37 and $55^{\circ} \mathrm{C}$. The shear rate was increased gradually from $0 \mathrm{~s}^{-1}$ to a larger shear, i.e., $50 \mathrm{~s}^{-1}$. Viscosity was then measured as a function of shear rate and shear stress at different temperatures. The most common equation that describes such behavior is the Power Law model,

$$
\tau=K|\dot{\gamma}|^{n}, n<1
$$

where $\tau=$ shear stress, $\mathrm{Pa}, \dot{\gamma}=$ shear rate, $\mathrm{s}^{-1}$, and $K=$ Apparent viscosity, Pascal.

\section{Results}

\subsection{Characterization of Soil a Recovered Oil from the Core Modelnd Oil Samples}

The heavy crude oil sample viscosity was determined as 17.193 and as 26.1 API. Soil $\mathrm{pH}$ was neutral to slightly alkaline ( $\mathrm{pH}$ 7.6). Analyses of the soil samples indicated that the soil was sandy with high carbon content; however, the number of hydrocarbons degrading microorganisms present was $2.4 \times 10^{7} \mathrm{CFU} \mathrm{g}{ }^{-1}$ dry soil. Moisture content of the soil was found to be 4.53 and 2.29 soil WHC.

The TPH of the soil sample was $6733.3 \mathrm{ppm}$. The mineral compositions of the soil samples measured by XRD showed that the soil samples contained Lepidocrocite, Microcline, and Wustite (Table 1). 
Table 1. Minerology composition of soil sample using XRD analysis.

\begin{tabular}{ccccc}
\hline Ref. Cod & Compound Name & Chemical Name & Chemical Formula & Approximate \% \\
\hline $44-1415$ & Lepidocrocite & Iron Oxide Hydroxide & $\mathrm{FeO}(\mathrm{OH})$ & 58.04 \\
$19-0932$ & Microcline & Potassium Aluminum Silicate & $\mathrm{KAISi}_{3} \mathrm{O}_{8}$ & 41.46 \\
$06-0615$ & Wustite & Iron Oxide & $\mathrm{FeO}$ & 0.50 \\
\hline
\end{tabular}

\subsection{Core Samples Analysis}

The core samples from Sirte Basin and formation type (Dolomite) were tested (date not shown). Lab experiments were performed by injecting live bacterial cells through core material (packed column).

\subsection{Molecular-Based Identification of Bacterial Isolates}

The isolates that could utilize heavy crude oil as a carbon source and showed maximum growth were isolated and selected for the study. The three bacterial isolates were characterized to the genus level based on the complete sequence of their $16 \mathrm{~S}$ ribosomal RNA gene. The sequences of $16 \mathrm{~S}$ rRNA were submitted to BLAST under accession numbers FM211694.1, AF282889.1, and AF526907, respectively, and the bacteria identified as shown in Table 2. It was not possible to obtain full identification to the species level of all the bacterial isolates.

Table 2. Identification of selected hydrocarbon-degrading bacterial isolates by $16 \mathrm{~S}$ rDNA gene sequence.

\begin{tabular}{cccc}
\hline Isolates & Species as Close Relatives & Accession No. & Similarity (\%) \\
\hline HKI & Pseudomonas putida & FM211694.1 & 100.0 \\
HKII & Bacillus sp. & AF526907 & 99.1 \\
HKIII & Nocardia cyriacigeorgica & AF282889.1 & 99.1 \\
\hline
\end{tabular}

\subsection{Effect of Temperature and Crude Oil Concentrations on the Growth of the 3 Bacterial Isolates}

Pure cultures of the three selected bacteria were supplemented with different concentrations of crude oil $-1.0,2.0$, and $3.0(\mathrm{v} / \mathrm{v})$ and incubated at 37 and $55{ }^{\circ} \mathrm{C}$ under controlled conditions. All species exhibited more favorable growth at temperatures of $55^{\circ} \mathrm{C}$ than at $37^{\circ} \mathrm{C}$, and hydrocarbon concentrations at $2.0 \%$. The optimum growth rates of the different isolates on $2.0 \%(v / v)$ of crude oil were calculated and showed that the Bacillus species and Pseudomonas putida grew quicker than the other isolate, Nocardia cyriacigeorgica, on hydrocarbons of $2.0 \%(v / v)$ at $55^{\circ} \mathrm{C}$. The maximum specific growth rate ( $\mu$ max) for the Bacillus species was $1.88 \mathrm{~h}^{-1}$, Pseudomonas putida was $1.734 \mathrm{~h}^{-1}$, and the Nocardia cyriacigeorgica was $0.764 \mathrm{~h}^{-1}$ (Table 3). Therefore, both Bacillus species and Pseudomonas putida gave the highest growth rate and were selected for further investigation.

Table 3. Growth rates of the three bacterial strains at different optimum concentrations of Bouri crude oil and different temperatures.

\begin{tabular}{|c|c|c|c|}
\hline Bacterial Species & Concentration in vol \% & Growth Rate $\mu h^{-1}$ at $37^{\circ} \mathrm{C}$ & Growth Rate $\mu \mathrm{h}^{-1}$ at $55^{\circ} \mathrm{C}$ \\
\hline & 1.0 & 0.397 & 1.252 \\
\hline \multirow[t]{3}{*}{ Bacillus species } & 2.0 & 0.445 & 1.89 \\
\hline & 3.0 & 0.161 & 0.784 \\
\hline & 1.0 & 0.208 & 1.514 \\
\hline \multirow[t]{3}{*}{ P. putida } & 2.0 & 0.651 & 1.734 \\
\hline & 3.0 & 0.119 & 0.772 \\
\hline & 1.0 & 0.205 & 0.786 \\
\hline \multirow[t]{2}{*}{ N. cyriacigeorgica } & 2.0 & 0.206 & 0.764 \\
\hline & 3.0 & 0.155 & 0.713 \\
\hline
\end{tabular}




\subsection{Oil Viscosity Reduction}

Oil viscosity was used as an indicator of microbial-induced compositional change in the crude oil after microbial treatment. Table 4 represents the change in viscosity of crude oil after microbial treatment at different shear rate values. Two temperatures were covered in this study $\left(37\right.$ and $\left.55^{\circ} \mathrm{C}\right)$ to examine the effect of temperature on the flow behavior of the heavy crude oil. The heavy crude oil viscosity decreases significantly from 13.827 to 3.597 Pas when the temperature changes from 37 to $55^{\circ} \mathrm{C}$.

Table 4. Comparing average viscosity of crude oil after using bacterial species at different temperature conditions.

\begin{tabular}{cccc}
\hline Temperature $\left({ }^{\circ} \mathrm{C}\right)$ & $\begin{array}{c}\text { Average Viscosity, Pa.s } \\
\text { Pseudomonas putida }\end{array}$ & $\begin{array}{c}\text { Average Viscosity, Pa.s } \\
\text { Bacillus Species }\end{array}$ & $\begin{array}{c}\text { Average Viscosity, Pa.s } \\
\text { Nocardia cyriacigeorgica }\end{array}$ \\
\hline 55 & 0.682388 & 1.39256 & 0.481724 \\
37 & 1.52084 & 6.22 & 0.428794 \\
\hline
\end{tabular}

Effect of Bacterial Isolates on Viscosity of Bouri Crude Oil

Specific quantitative lab procedures using a Rotational Viscometer (CV100) were carried out to measure the shift in rheological properties in treated (inoculated) samples. The reduction of oil viscosity to enhance the flow properties occurs due to effects of bacterial degradation of oil or excreting of components such as surfactants into the oil phase. Figure 1 at $37^{\circ} \mathrm{C}$ and Figure 2 at $55^{\circ} \mathrm{C}$ show a sharp decrease in viscosity at a shear rate below $3 \mathrm{~s}^{-1}$, and after $50 \mathrm{~s}^{-1}$ the viscosity remains steady.

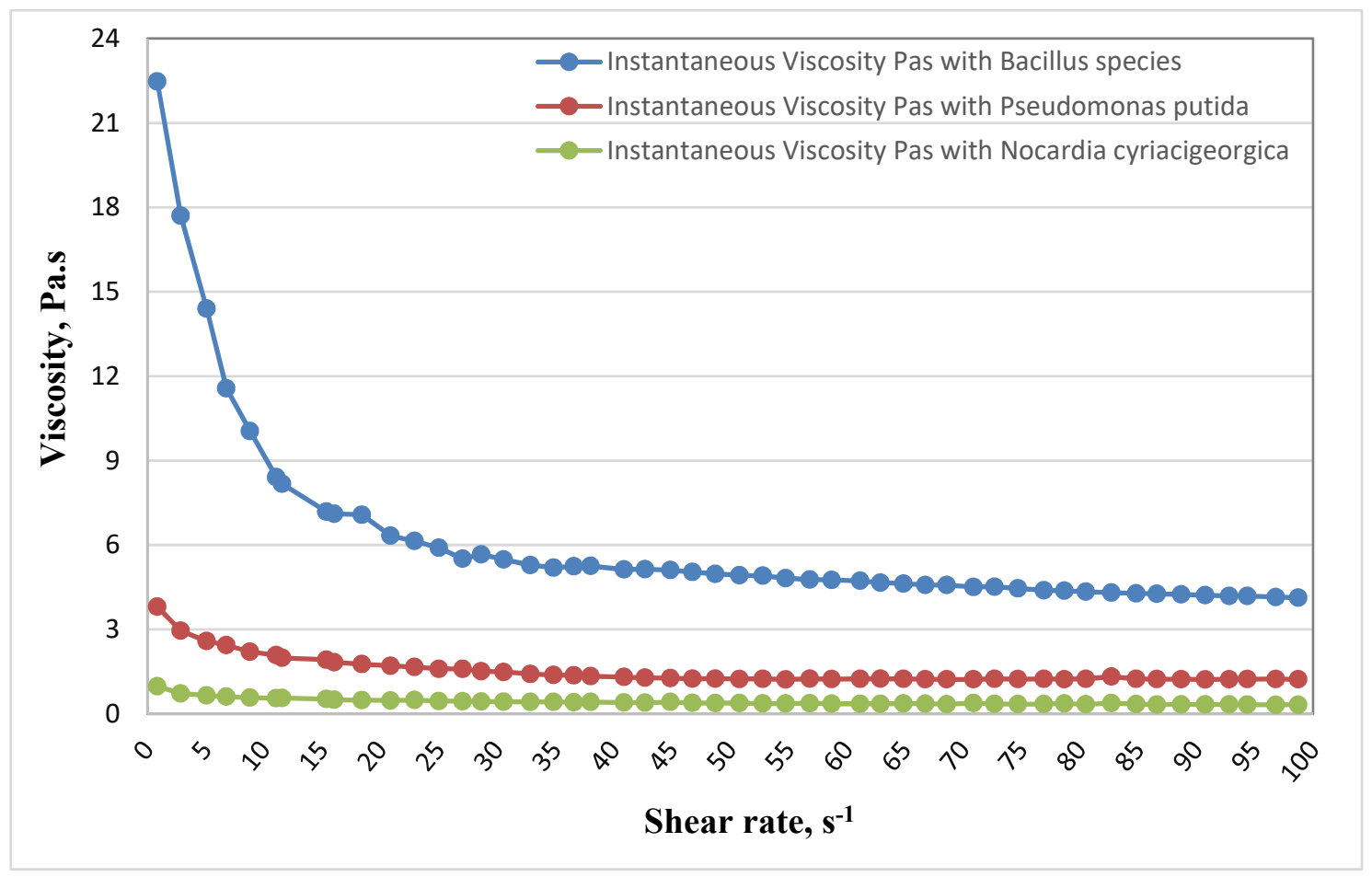

Figure 1. Reduction in viscosity of crude oil treated with Bacillus species, Pseudomonas putida, and Nocardia cyriacigeorgica at $37^{\circ} \mathrm{C}$.

The viscosity of crude oil treated with Bacillus species was significantly decreased from 22.47 Pa.s at $0.8481 \mathrm{~s}^{-1}$ to 4.127 Pa.s at $98.73 \mathrm{~s}^{-1}$ at a temperature of $37^{\circ} \mathrm{C}$; comparing with the efficiency of the Pseudomonas putida, the viscosity reduction was from 3.806 Pa.s at $0.7652 \mathrm{~s}^{-1}$ to 1.226 Pa.s at $98.64 \mathrm{~s}^{-1}$. Nocardia cyriacigeorgica reduced oil viscosity from 0.9786 Pa.s at $0.8226 \mathrm{~s}^{-1}$ to 0.3224 Pa.s at $98.79 \mathrm{~s}^{-1}$ (Figure 1). 


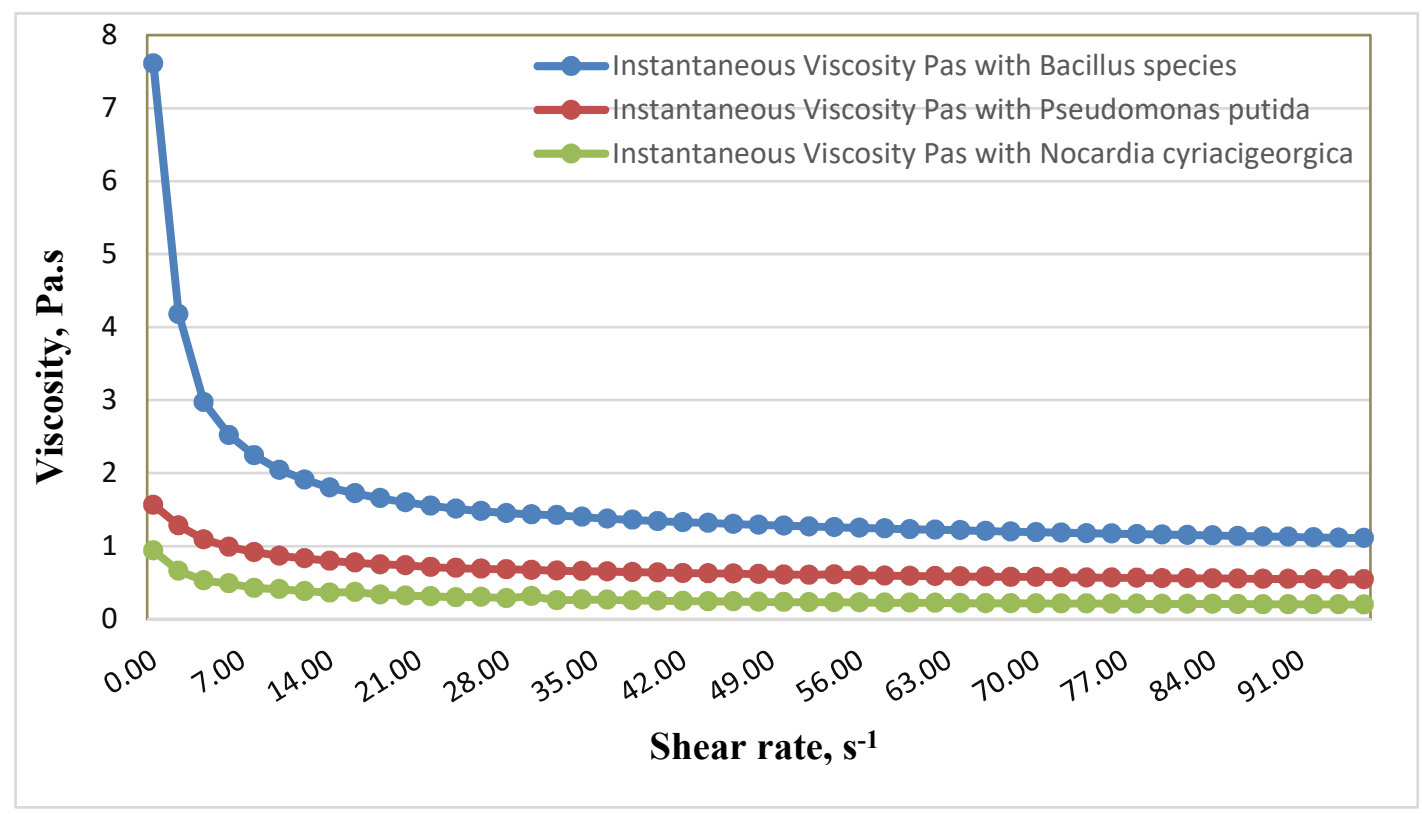

Figure 2. Reduction in viscosity of crude oil treated with Bacillus species, Pseudomonas putida, and Nocardia cyriacigeorgica at $55^{\circ} \mathrm{C}$.

At a temperature of $55^{\circ} \mathrm{C}$, the viscosity of crude oil treated with Bacillus species was significantly decreased from 7.61 Pa.s at $0.885 \mathrm{~s}^{-1}$ to 1.11 Pa.s at $96.74 \mathrm{~s}^{-1}$. The result further showed that the Bacillus species can be successfully used at high temperatures. The reduction in viscosity was decreased from 1.565 Pa.s at $0.7622 \mathrm{~s}^{-1}$ to 0.5415 Pa.s at $98.67 \mathrm{~s}^{-1}$ with Pseudomonas putida. Nocardia cyriacigeorgica reduced viscosity from 0.9406 Pa.s at $0.885 \mathrm{~s}^{-1}$ to 0.1998 Pa.s at $96.74 \mathrm{~s}^{-1}$ (Figure 2).

There was no significant change of $\mathrm{pH}$, indicating that no acidic byproducts were produced during the incubation period.

\subsection{Crude Oil Transformation}

The collected oil fractions from the flood water before and after the incubation with bacteria strains were analyzed by GC. The results of gas chromatograms indicated that there was a marked change in GC chromatograms for Bouri crude oil treated with three strains when compared with control untreated crude oil. A comparison of the profiles in Figures 3 and 4 illustrates a decrease in the weight percentage of carbon number fractions before and after treatment with Bacillus species, Pseudomonas putida, and Nocardia cyriacigeorgica.

The analysis data of the Gas chromatograms confirmed that the biotransformation produced important changes in the composition of the Bouri crude oil. The microbial transformation of $2.0 \%$ Bouri crude oil at temperature $55{ }^{\circ} \mathrm{C}$ was higher than that obtained at temperature $37^{\circ} \mathrm{C}$.

At temperature $55^{\circ} \mathrm{C}$ Bacillus species showed a significant decrease in carbon fraction (C12 to C33). A sharp reduction of heavy fraction (C22 to C33) with Pseudomonas putida treatment was observed; this was probably because this microbe utilized the heavy fraction before the light fraction. A similar trend was also observed in the case of treatment with Nocardia cyriacigeorgica, where the analysis showed $77 \%$ biotransformation of heavy crude oil for Bacillus species, and $61 \%$ for Pseudomonas putida and Nocardia cyriacigeorgica.

At temperatures of $37^{\circ} \mathrm{C}$, Bacillus species can degrade lighter hydrocarbons with a carbon chain length of (C12-C24) and heavier hydrocarbons with a carbon chain length of (C24-C33). However, Pseudomonas putida and Nocardia cyriacigeorgica exhibited better degradation on heavier hydrocarbons with carbon chain length of (C24-C33), the analysis 
showed $66 \%$ biotransformation of heavy crude oil for Bacillus species, $45 \%$ for Pseudomonas putida, and $16 \%$ with Nocardia cyriacigeorgica.

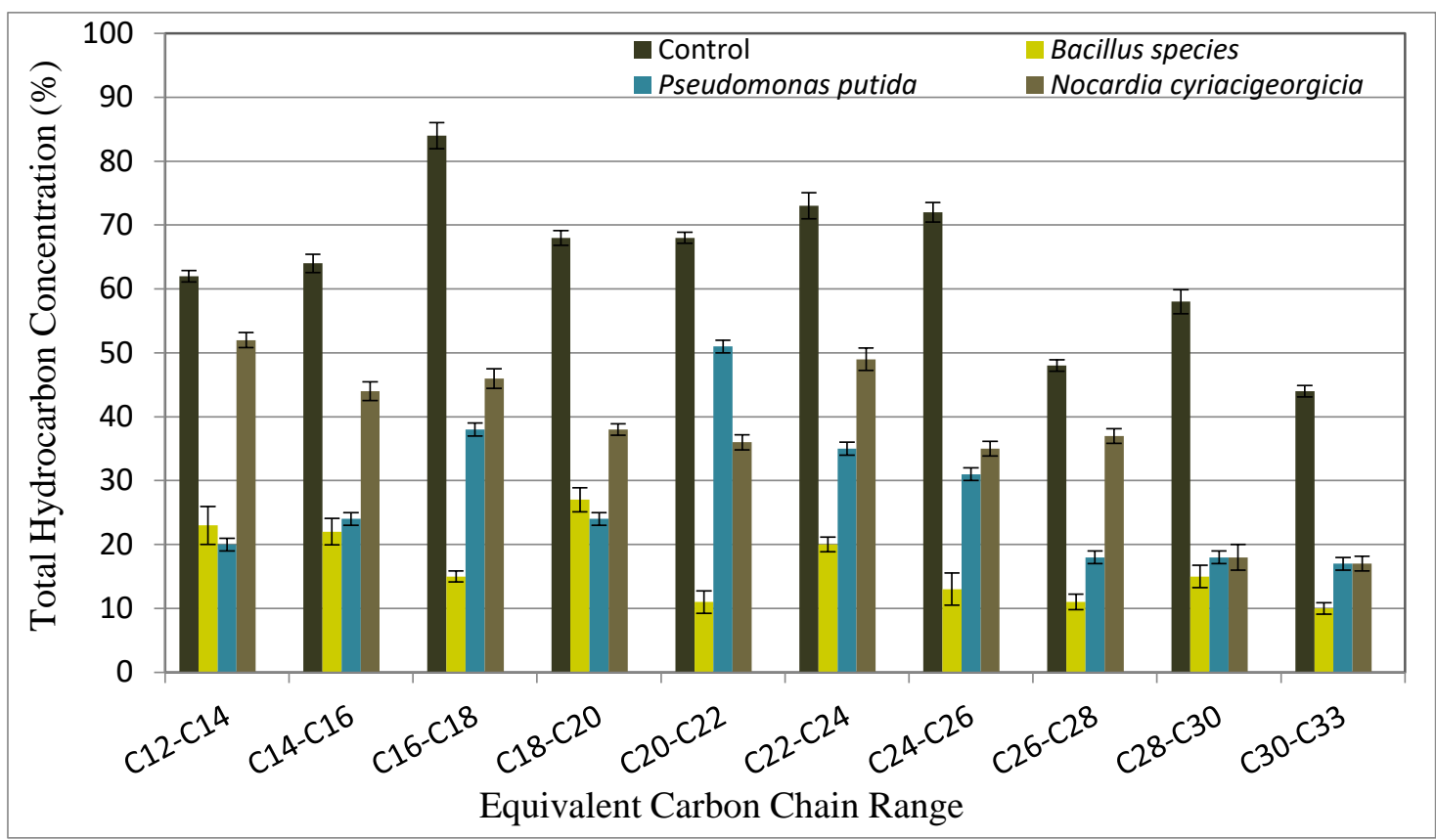

Figure 3. GC-MS Analysis of heavy crude oil biotransformation by Pseudomonas putida, Bacillus species and Nocardia cyriacigeorgica at $55^{\circ} \mathrm{C}$ on day 21 ; as compared to the control.

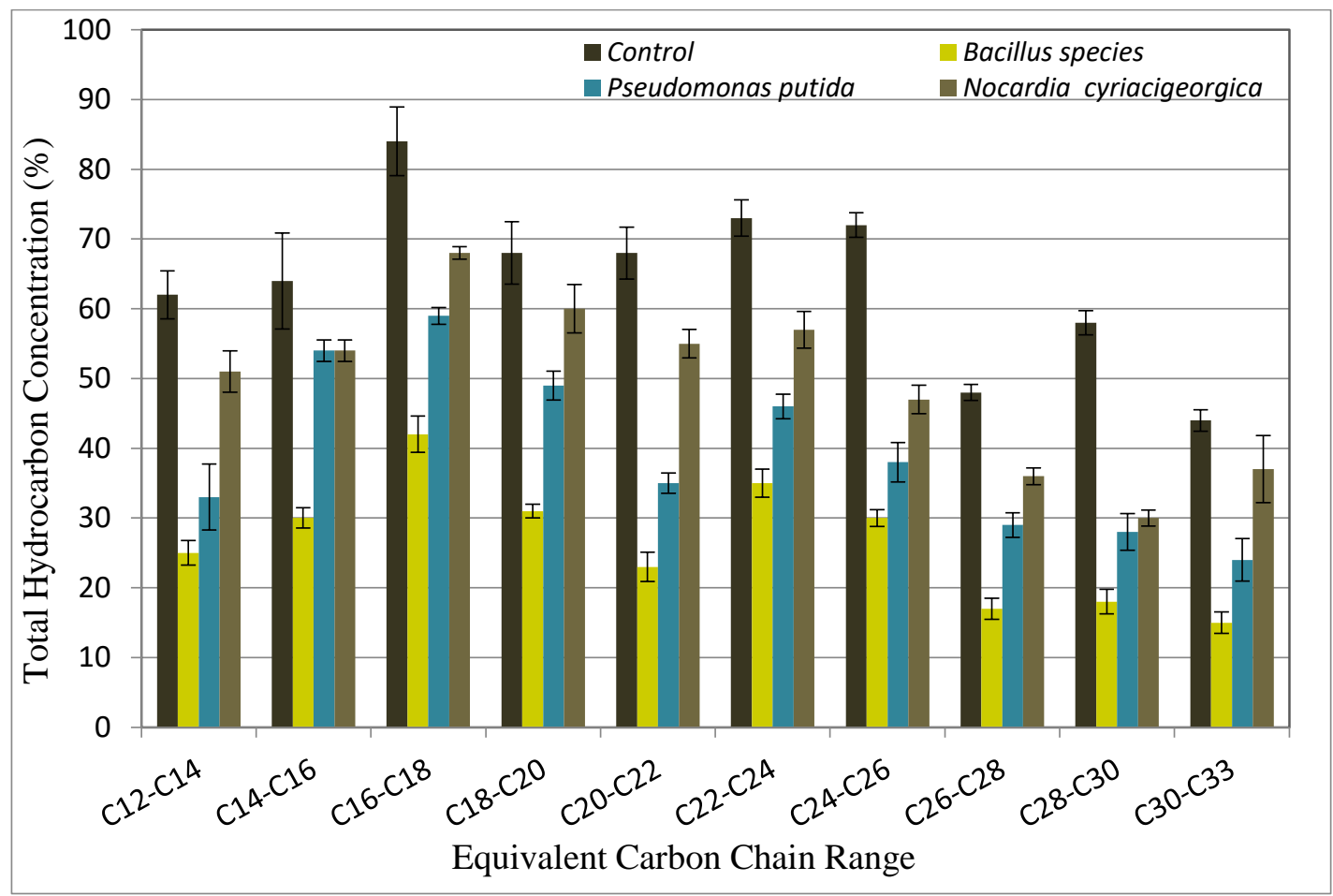

Figure 4. GC-MS Analysis of heavy crude oil biotransformation by Pseudomonas putida, Bacillus species and Nocardia cyriacigeorgica at $37^{\circ} \mathrm{C}$ on day 21 ; as compared to the control. 


\subsection{Recovered Oil from the Core Model}

Dolomite sandstone cores were used to evaluate the potential of isolates in heavy oil recovery. After 12 weeks incubation, 7.9 to $11.38 \%$ additional oil-in-place was recovered. The oil initially in place (OIIP) in the core for Nocardia cyriacigeorgica was $11.4 \mathrm{~mL}$ (Soi $=63.6 \%$ ). After injecting 5-8 PV of formation water, no more oil was produced and residual oil saturation (Soi) was about $20 \%$, which resulted in the recovery of $50.87 \%$ of initial oil (OI), corresponding to $5.8 \mathrm{~mL}$ of the initial oil present in the core. The column was reinjected with 5-6 PV of brine that resulted in a total recovery of $58.77 \%(6.7 \mathrm{~mL})$ of initial oil present in the core in which $7.9 \%(0.9 \mathrm{~mL})$ was produced by the isolate.

With core treated by Pseudomonas putida, the oil initially in place (OIIP) was determined at $12.2 \mathrm{~mL}$ (Soi $=82.31 \%$ ). The water flooding resulted in recovery of $54.09 \%(6.6 \mathrm{~mL})$ of OIIP. Initial oil saturation (Soi) was calculated to be $63 \%$ after being injected with 5-6 PV of oil, which was indicated by the volume of water displaced. A total recovery of $64.75 \%$ $(7.2 \mathrm{~mL})$ of initial oil present in the core was recorded. An increase in oil recovery of $10.66 \%$ $(0.6 \mathrm{~mL})$ was detected after 12 week incubation.

The oil initially in place (OIIP) in the core for Bacillus species was determined, $12.3 \mathrm{~mL}$, Soi $=84.02 \%$. The water flooding resulted in recovery of $52.84 \%(6.5 \mathrm{~mL})$ of OIIP. Initial oil saturation was calculated to be $63 \%$ after being injected with 5-6 PV of oil, which was indicated by the volume of water displaced, that resulted in a total recovery of $64.22 \%$ $(7.9 \mathrm{~mL})$ of initial oil present in the core. After 12 weeks an increase in oil recovery of $11.38 \%(1.4 \mathrm{~mL})$ by Bacillus species was detected.

\section{Discussions}

Experiments were conducted on the growth of bacteria, adsorption of bacterial cells and metabolites on dolomite rocks, reduction in viscosity, and biotransformation of crude oil. In this study, three strains, Bacillus species, Pseudomonas putida, and Nocardia cyriacigeorgica, with potential for biotransforming heavy crude oil were isolated from heavy crude oil-contaminated soil samples collected from Libyan oil fields. The potential of three identified microbial genera for EOR was reported for the first time in Libya.

The reservoir factors such as temperature, salinity, $\mathrm{pH}$, and pore size affect the effectiveness of microbes in the reservoir [19]. The isolated strains were grown in $\mathrm{pH}$ between $6-8$ and a crude oil range of $1.0-3.0 \%$. The growth of the bacterial species was increased with increased crude oil concentration to an optimum at $2.0 \%$ concentration and only limited growth occurred when the concentration was further increased to $3.0 \%$. Higher concentrations of hydrocarbons might inhibit biodegradation by limiting access to nutrient or oxygen supply or by its toxic effects [20].

Experience has shown that, with careful planning and repeated sub-culturing, it is possible that these strains can grow at higher crude oil concentrations normally encountered in the reservoirs; however, this was not investigated further in this study.

Based on optimum temperatures for growth and crude oil concentration requirements, the optimum temperature of the three facultative anaerobes, Bacillus species, Pseudomonas putida and Nocardia cyriacigeorgica, was $55^{\circ} \mathrm{C}$, while they did not grow at temperatures above $60^{\circ} \mathrm{C}$. This was similar to the optimum temperature range reported by Chen et al. [21]. Methanobacterium showed optimum growth temperatures of 63 to $66{ }^{\circ} \mathrm{C}$ with a specific growth rate of $0.62 \mathrm{~h}^{-1}$ [22]. Many oil reservoirs have an initial temperature greater than $75^{\circ} \mathrm{C}$ but due to continuous injection of water for oil recovery over time, the temperature becomes much less than the initial reservoir temperature as the field matures [23]. The modeling work presented in the previous sections showed that the potential strains used can withstand both high crude oil concentration $(2.0 \%)$ and high temperature conditions $\left(55^{\circ} \mathrm{C}\right)$. Lower growth rates were recorded at $37^{\circ} \mathrm{C}$ with different concentrations of Bouri crude oil (1.0, 2.0, and 3.0\%). Only the Bacillus species gave good growth with crude oil concentrations of $2.0 \%$.

Many of the bacteria strains used in MEOR usually experienced low efficiency when maintained at higher temperatures, but Bacillus species and Pseudomonas putida were able to 
exhibit good potential with crude oil concentrations of $2.0 \%$ at high temperature. However, what makes these strains better lies in their ability to grow at a high temperature of $55^{\circ} \mathrm{C}$, in comparison to many bacteria isolated for microbial enhanced oil recovery purposes. The microorganisms that are most used for MEOR field processes are species of Bacillus and Clostridium. These species produce spores, which are resistant stages, allowing them to survive in petroleum reservoirs and more stressful environmental conditions [24].

\section{Transformation of Hydrocarbon}

The GC analysis showed that heavy oil that is trapped in an oil reservoir after primary and secondary recovery can be recovered by biotransforming the heavier fractions to lighter ones. The results have demonstrated that not all the alkanes were equally reduced as a difference was recorded (Figures 3 and 4).

Comparing these results with other reports, the Bacillus species isolated from a natural environment had the ability to degrade the heavy fraction of crude oil and change the chemical and physical properties of Bouri crude oil. Close strains such as B. firmus and $B$. halodurans were shown to result in the fractionation of higher $n$-alkanes with carbon numbers up to C54 [1].

The microbial degradation of oil and biosurfactants production are major factors taking place during microbial water injection, microbial activities, and interactions of metabolic products with oil and cores contributing to the enhancement of oil recovery $[25,26]$. The addition of Thermoanerobacter brockii subsp. Lactiethylicus 9801T was reported to degrade alkanes and produce important metabolites such as biosurfactants and gases which positively contribute to the oil recovery process [27].

The percentage of heavier and lighter hydrocarbons was reduced to 77 and $63 \%$, respectively, during the period of incubation $\left(55^{\circ} \mathrm{C}\right)$ with Bacillus species, and $66 \%$ on heavier fractions of Bouri crude oil at $37^{\circ} \mathrm{C}$.

Pseudomonas putida and Nocardia cyriacigeorgica have decreased the concentration of heavier hydrocarbons $\mathrm{C} 22+$, to $61 \%$ at $55^{\circ} \mathrm{C}$. On the other hand, a slight decrease in lighter hydrocarbons of $45 \%$ and $16 \%$, respectively, was recorded for both species at $37^{\circ} \mathrm{C}$. The crude oil utilization capability and degradation potential of both Pseudomonas and Bacillus sp. were reported in previous studies [28,29].

The heavy crude oil biodegradation and biotransformation were evident by the decrease in lighter and heavier compounds. Bacterial strains were found to destroy heavier fractions which led to an increased API of crude and tended to reduce viscosity, thus increasing the oil's mobility and flow characteristics. Moreover, the degradation of alkanes was also very significant, probably from the effect of biosurfactants production (data not shown). These findings suggest that the bacterial strains used may be potential candidates for the biotransformation of heavy crude oil.

The isolated bacteria strains (Pseudomonas putida, Bacillus species, and Nocardia cyriacigeorgica) significantly decreased the oil viscosity from $22.47 \mathrm{~Pa}$.s at $0.8481 \mathrm{~s}^{-1}$ to $4.127 \mathrm{~Pa} . \mathrm{s}$ at $98.73 \mathrm{~s}^{-1}$. According to [30], using microbes for biodegrading long chain paraffins may have the following benefits: the amount of paraffin will be reduced, resulting in reduced paraffin precipitation or deposition problems along the production flow line, and as a result the viscosity of crude oil will be reduced, increasing its API gravity.

The microbial degradation of crude oil results in its dissolution away from the block and eventually being carried out in porous media while simultaneously resulting in the phenomenon of swept volume expansion that remarkably improves the oil displacement effect [31].

The isolates were shown to be feasible for similar applications in a number of laboratory experiments reported before. However, they have not been widely used in heavy oil-saturated dolomite sandstone cores before and, since rock properties, such as mineral content, grain and pore size, porosity, permeability, under some physical and chemical conditions that resemble those experienced in an oil production reservoir can vary, such as high salinities and temperatures, this study highlights the novelty of using these strains, 
Bacillus species, Pseudomonas putida and Nocardia cyriacigeorgica, as excellent candidates that can reduce oil viscosity, leading to some biotransformation and an increase in oil recovery.

$N$. cyriacigeorgica was reported to degrade aliphatic and branched chain alkanes as well as alkylbenzene of oil in contaminated soils [32], whereas in the current study this isolate showed the ability to biotransform heavy oil with an API gravity value of $26^{\circ}$, reducing its viscosity and increasing the oil recovery to $7.9 \%$. In a bioaugmentation treatment to remove hydrocarbons, Pseudomonas putida CB-100 enhanced TPH decontamination of contaminated aged soil; $40.6 \%$ of total petroleum hydrocarbons (TPH) was removed and $1.54 \mathrm{mg} / \mathrm{kg}$ rhamnolipid was reported produced [33]. Our P. putida utilized the heavy fraction of heavy crude oil and gave $61 \%$ of biotransformation, a reduction in viscosity from 1.565 Pa.s at $0.7622 \mathrm{~s}^{-1}$ to 0.5415 Pa.s at $98.67 \mathrm{~s}$, and, interestingly, increased the oil recovery by $10.66 \%$.

Considerable oil recovery has been obtained by the biotransformation of heavy crude oil compared to the control experiment. The extra recovery measurements were based on the residual oil present in the core. The highest recovery of residual oil among different bacterial species was approximately $11.38 \%$ at $55^{\circ} \mathrm{C}$ by Bacillus species. Similar results were reported by [34], where an additional recovery of $9.6 \%$ at $37{ }^{\circ} \mathrm{C}$ and $7.2 \%$ at $55{ }^{\circ} \mathrm{C}$ of crude oil 26 API occurred due to the combined effect of biosurfactants and the biotransforming ability of Bacillus spp. In addition, $14.3 \%$ oil recovery for unfractured core models was recorded by [35] using a different indigenous microorganism isolated from oil samples from the Payedar oilfield.

Oil recovery can generally be improved by 5\% using microbial flooding solely [36]. This approach has a significant effect of the fracture angle on performance of the process and has indicated that oil recovery was increased by $6-10 \%$ of initial oil in place using microbial mediated oil, depending on oil saturation at the start of the flooding [37].

\section{Conclusions}

Local isolates of Pseudomonas putida, Bacillus species, and Nocardia cyriacigeorgica were able to grow at higher concentrations of heavy crude oil, effectively converting heavy fractions of crude oil to lighter fractions and indicating their potential application in microbial-enhanced oil recovery processes. Bacterial biotransformation of Bouri crude oil showed significant dependence on temperature as an important parameter.

Viscosity was studied versus shear rate and temperature. The control sample showed that the use of these bacteria can alter crude to a significant extent. The three isolates considerably improved oil production and reduced oil viscosity. Isolates Pseudomonas putida and Bacillus species were both demonstrated to be promising candidates for MEOR applications. The extra recovery of crude heavy oil in the sand-packed column experiments and migration of bacteria in porous sandstone cores further confirmed this.

In conclusion, MEOR is an eco-friendly cost-effective technique with various benefits over other chemical EOR methods and the isolated strains can result in additional oil as a part of the tertiary oil recovery process.

Supplementary Materials: The following are available online at https: / www.mdpi.com/article / $10.3390 /$ app112110492/s1. The aligned sequences of the representative strains retrieved from the GenBank (NCBI, USA) database and test strain were used to generate phylogenetic tree and similarity matrices using the PHYLIP.

Author Contributions: Author conceptualization, H.A.A., data curation, H.A.A. and I.M.E., formal analysis, methodology, H.A.A. and I.M.E.; writing-original draft, H.A.A. and I.M.E.; review and editing, H.A.A. and I.M.B., Supervision, H.A.A. All authors have read and agreed to the published version of the manuscript.

Funding: This work was financed by Libyan Petroleum Institute (LPI).

Institutional Review Board Statement: Not applicable.

Informed Consent Statement: Not applicable. 
Data Availability Statement: All datasets generated or analysed for this study are included in the manuscript and the Supplementary Materials. The data for the three genomes of bacterial spp. isolates were deposited at NCPI/GenBank in the Bioproject PRJNA433829.

Acknowledgments: We are extremely grateful for the help of the staff at the Reservoir Rocks lab \& Ashraf Amora at GC lab, and the technical assistance from Fathia Albshtei at Rheology lab (Tripoli Libya).

Conflicts of Interest: The authors declare no conflict of interest.

\section{References}

1. Shibulal, B.; Al-Bahry, S.N.; Al-Wahaibi, Y.M.; Elshafie, A.E.; Al-Bemani, A.S.; Joshi, S.J. Microbial-Enhanced Heavy Oil Recovery under Laboratory Conditions by Bacillus firmus BG4 and Bacillus halodurans BG5 Isolated from Heavy Oil Fields. Colloids Interfaces 2018, 2, 1. [CrossRef]

2. Banat, I.M. Biosurfactants Production and Use in Microbial Enhanced Oil Recovery and Pollution Remediation: A Review. Bioresour. Technol. 1995, 51, 1-12. [CrossRef]

3. Fratesi, S.E. Distribution and Morphology of Microorganism and Their Byproduct in Enhanced Oil Recovery Operations. Master's Thesis, Mississippi State University, Starkville, MI, USA, 2002.

4. Behlulgil, K.; Mehmetoglu, M.T. Bacteria for Improvement of Oil Recovery: A Laboratory Study. Energy Sources 2002, 24, 413. [CrossRef]

5. Joshi, S.; Bharucha, C.; Jha, S.; Yadav, S.; Nerurkar, A.; Desai, A.J. Biosurfactant Production Using Molasses and Whey under Thermophilic Conditions. Bioresour. Technol. 2008, 99, 195-199. [CrossRef] [PubMed]

6. $\quad$ Elshafie, A.E.; Joshi, S.J.; Al-Wahaibi, Y.M.; Al-Bemani, A.S.; Al-Bahry, S.N.; Al-Maqbali1, D.; Banat, I.M. Sophorolipids Production by Candida bombicola ATCC 22214 and its Potential Application in Microbial Enhanced Oil Recovery. Front. Microbiol. 2015, 6, 1324. [CrossRef]

7. Lazar, I.; Petrisor, I.G.; Yen, T.F. Microbial Enhanced Oil Recovery (MEOR). Pet. Sci. Technol. 2007, 25, 1353-1366. [CrossRef]

8. Al-Bahry, S.N.; Al-Wahaibi, Y.M.; Elshafie, A.E. Biosurfactant production by Bacillus subtilis B20 using date molasses and its possible application in enhanced oil recovery. Int. Biodeterior. Biodegrad. 2013, 81, 141-146. [CrossRef]

9. Bundy, G.J.; Paton, G.I.; Campbell, C.D. Combind Microbial Community Level and Single Species Biosensor Responses to Monitor Recovery of Oil Polluted Soil. Soil Biol. Biochem. 2004, 36, 1149-1159. [CrossRef]

10. ASTM. American Standard Test Method C01, 2007. ASTM D4972, "Standard Test Method for pH of Soils"; ASTM International: West Conshohocken, PA, USA, 2003. Available online: www.astm.org (accessed on 1 November 2021). [CrossRef]

11. Wilke, B.-M. Determination of Chemical and Physical Soil Properties in Monitoring E Assessing Soil Bioremediation; Springer: Berlin/Heidelberg, Germany, 2005; Volume 5, pp. 47-95.

12. Kim, S.; Choi, D.; Oh, Y. Evaluation of Bioremediation Effectiveness on Crude Oil- Contaminated Sand. Chemosphere 2005, 59, 845-852. [CrossRef]

13. Plaza, G.A.; Lukasik, K.; Wypych, J.; Nalecz-Jawecki, G.; Berry, C.; Brigmon, R.L. Biodegradation of Crude Oil and Distillation Products by Biosurfactant-Producing Bacteria. Pol. J. Environ. Stud. 2008, 17, 87-94.

14. Althalb, H.; Singleton, I. Isolation of Indigenous Hydrocarbon Transforming Bacteria from Oil Contaminated Soilin Libya: Selection for Use as Potential Inocula for Soil Bioremediation. Int. J. Environ. Biodeterior. Biodegrad. 2017, 5, 8-17.

15. Ueno, A.; Ito, Y.; Yamamoto, Y.; Yumoto, I.; Okuyama, H. Bacterial Community Changes in Diesel-Oil-Contaminated Soil Microcosms Biostimulated with Luria-Bertani Medium or Bioaugmented with a Petroleum-Degrading Bacterium, Pseudomonas aeruginosa strain WatG. Basic Microbiol. 2006, 46, 310-317. [CrossRef] [PubMed]

16. Song, H.G.; Wang, X.; Bartha, R. Bioremediation Potential of Terrestrial Fuel Spills. Appl. Environ. Microbiol. 1990, 56, 652-656. [CrossRef] [PubMed]

17. Vieira, P.A.; Vieira, R.B.; Franc, F.P.D.; Cardoso, V.L. Biodegradation of Effluent Contaminated with Diesel Fuel and Gasoline. J. Hazard. Mater. 2007, 140, 52-59. [CrossRef]

18. Ahmed, T. Reservoir-Fluid Properties, Reservoir Engineering Handbook, 3rd ed.; Elsevier: Oxford, UK, 2006 ; p. 76.

19. Nnaemeka, O.; Franklin, N.; Stanley, O. A Review of Microbial Enhanced Oil Recovery Applications Projects. Oil Gas Res. 2018, 4, 2. [CrossRef]

20. Palanisamy, N.; Ramya, J.; Kumar, S.; Vasanthi, N.S.; Chandran, P.; Khan, S. Diesel Biodegradation Capacities of Indigenous Bacterial Species Isolated from Diesel Contaminated Soil. J. Environ. Health Sci. Eng. 2014, 12, 142. [CrossRef]

21. Chen, Z.; Feng, Q.; Liu, R.; Chen, J.; Ni, F. Development and Application of Thermophilic Microorganism Species in Oil Recovery. Acta Pet. Sin. 2001, 22, 59-62.

22. Kitaura, S.; Nishimura, N.; Mimura, A.; Takahara, Y. Isolation and characterization of a fast-growing, thermophilic, hydrogenotrophic methanogen. J. Ferment. Bioeng. 1992, 74, 244-247. [CrossRef]

23. Jimoh, I.A.; Søgaard, E.G.; Rudyk, S.N. Spectroscopy and Image Analysis Characterization of Adapted Strains of Clostridium tyrobutyricum for Microbial Enhanced Oil Recovery Purposes. GSTF J. Biosci. 2012, 1, 36-41. 
24. Al-Sulaimani, H.; Al-Wahaibi, Y.; Al-Bahry, S.; Elshafie, A.; Al-Bemani, A.; Joshi, S.; Ayatollahi, S. Oil Recovery through Injection of Biosurfactant Chemical Surfactant, and Mixtures of Both under Reservoir Temperatures: Induced-wettability and interfacial-tension effects. SPE Reserv. Eval. Eng. 2012, 15, 210-217. [CrossRef]

25. Mu, B.; Wu, Z.; Chen, Z.; Wang, X.; Ni, F.; Zhou, J. Wetting Behavior on Quartz Surfaces by the Microbial Metabolism and Metabolic Products. In Proceedings of the 7th International Symposium on Wettability and Its Effects on Oil Recovery, Tasmania, Australia, 12-14 March 2002.

26. Geetha, S.J.; Banat, I.M.; Joshi, S.J. Biosurfactants: Production and Potential Applications in Microbial Enhanced Oil Recovery (MEOR). Biocatal. Agric. Biotechnol. 2018, 14, 23-32.

27. Rudyk, S.N.; Sogaard, E.G. Microbial Enhanced Oil Recovery. In Applied Microbiology and Molecular Biology in Oilfield Systems: Microbial EOR; Whitby, C., Skovhus, T.L., Eds.; Springer: Dordrecht, The Netherlands, 2011; pp. 179-187.

28. Sepahi, A.A.; Golpasha, I.D.; Emami, M.; Nakhoda, A. Isolation and Characterization of Crude Oil Degrading Bacillus spp. J. Environ. Health Sci. Eng. 2008, 5, 149-154.

29. Su, S.; Dong, H.; Chai, L.; Zhang, X.; Banat, I.M.; Wang, Z.; Hou, D.; Zhang, F.; She, Y. Dynamics of a Microbial Community during an Effective Boost MEOR Trial using High-Throughput Sequencing. R. Soc. Chem. Adv. 2017, 8, 690-697. [CrossRef]

30. Sadeghazad, A.; Ghaemi, N. Microbial Prevention of Wax Precipitation in Crude Oil by Biodegradation Mechanism. In SPE Asia Pacific Oil and Gas Conference and Exhibition; Society of Petroleum Engineers: Jakarta, Indonesia, 2003.

31. Yue, M.; Zhu, W.; Song, Z.; Long, Y.; Song, H. Study on Distribution of Reservoir Endogenous Microbe and Oil Displacement Mechanism. Saudi J. Biol. Sci. 2017, 24, 263-267. [CrossRef] [PubMed]

32. Le, T.C.; Mikolasch, A.; Awe, S.; Sheikhany, H.; Klenk, H.P.; Schauer, F. Oxidation of aliphatic, branched chain, and aromatic hydrocarbons by Nocardia cyriacigeorgica isolated from oil-polluted sand samples collected in the Saudi Arabian Desert. J. Basic Microbiol. 2010, 50, 241-253. [CrossRef] [PubMed]

33. Angeles, M.T.; Refugio, R. In situ biosurfactant production and hydrocarbon removal by Pseudomonas putida CB-100 in bioaugmented and biostimulated oil-contaminated soil. Braz. J. Microbiol. 2013, 44, 595-605. [CrossRef]

34. Wu, L.; Yao, J.; Jain, A.K.; Radhika, C.; Xudong, D.; Hans, R.H. An Efficient Thermotolerant and Halophilic BiosurfactantProducing Bacterium Isolated from Dagang Oil Field for MEOR Application. Int. J. Curr. Microbiol. Appl. Sci. 2014,3 , 586-599.

35. Abtahi, N.; Roostaazad, R.; Ghadiri, F. Biosurfactant Production in MEOR for Improvement of Iran's Oil Reservoirs' Production Experimental Approach. SPE84907. In Proceedings of the SPE International Improved Oil Recovery Conference in Asia Pacific, Kuala Lumpur, Malaysia, 20-21 October 2003.

36. Mei, S.; Wei, L.; Guangzhi, L.; Peihui, H.; Zhaowei, H.; Xinghong, C.; Ying, W. Laboratory Study on MEOR after Polymer Flooding. SPE84865. In Proceedings of the SPE International Improved Oil Recovery Conference in Asia Pacific, Kuala Lumpur, Malaysia, 20-21 October 2003.

37. Salehizadeh, H.; Mohammadizad, S. Microbial enhanced oil recovery using biosurfactant produced by Alcaligenes faecalis. Iran. J. Biotechnol. 2009, 7, 216-223. 